\title{
Selected Bibliography of Materials \\ on Russian Folklore
}

\section{James Bailey, U W Madison}

As everyone who has tried to follow and perhaps to purchase recent books about Russian folklore knows, there no longer is any certain way of finding out what is actually published in Russia. The whole system has changed, old publishing houses have vanished, new ones have appeared, many items appear in provincial cities, and there is no central listing of current or planned publications. Short bibliographies appear in the somewhat popular journal Zhivaia starina which is coming out for the third year. The present bibliography contains a selection of books that have appeared since 1990 and surveys trends that may be taking place.

While a rather broad interest exists in publishing items concerned with Russian nationality, ethnography, ethnomusicology, folklore, customs, and beliefs, there also are many books that have a popular appeal, are of questionable scholarly quality. and reflect an interest in astrology. the occult, or the supernatural. One disturbing sign is that very few collections of Russian folklore itself are coming out, perhaps because private publishers see little demand for it, but this may also reflect the fact that institutions have few funds to finance expeditions to collect folklore in the field. Thanks to a new system of grants, Russian scholars may compete for funds from several organizations to publish their manuscripts. Because of publishing costs, plans for bringing out the long. desired compendium of Russian epics, for instance, have been again postponed even though the first few volumes are ready for publication.

At the same time there are several positive signs for the study of Russian folklore today because a number of new fine scholarly works are appearing, many older "classics" are being republished, basic reference works are coming out, and neglected genres such as incantations, memorates (bylichki), and spiritual verses (dukhovnye stikhi) are being published either separately or in anthologies. It seems that only occasional efforts are being made to adapt the study of Russian folklore to American "Dorsonism," although S. Iu. Nekliudov in his article "Posle fol'klora," Zhivaia starina (1995, no. 1: 2-4), makes a plea for such an approach to collect and study contemporary folklore. 
The items have been divided into several general groups. Comments, suggestions, additions, and corrections would be appreciated. Email: <JOBailey: facstaff.wisc.edu>.

REFERENCE WORKS. Several bring together compendia of Russian folk beliefs or address Slavic mythology.

Narodnye znanila, folklor, narodnoe iskusstvo: Svod etnograficheskikh poniatii i terminov. Eds. B. N. Putilov and G. Shtrobakh. Moscow: Nauka, 1991. Novichkova, T. A. Russkii demonologicheskii slovar'. $\mathrm{SPb} .:$ Petersburgskii pisatel, 1995. (Contains many memorates and draws on archival materials.)

Radford, E. and M. A., E. Minenok. Entsiklopediia sueverii. M.: Lokid and Mif, 1995. (Contains translations from the compilation of English beliefs by the Radfords and parallel Russian beliefs.) Rossiiskie folkloristy: Spravochnik. Comp. L. V. Rybakova. M.: Indrik, 1994. (A "who's who" of Russian folklorists.)

Russkii folklor: Bibliograficheskii ukazatel 19811985. T. G. Ivanova, comp. St. Petersburg: Biblioteka Rossiikoi Akademii Nauk, 1993. Russkii folklor: Bibliograficheskii ukazatel 18001855. T. G. Ivanova, comp. St. Petersburg: Institut russkoj literatury, 1996. (The latest two volumes in this indispensable series of bibliographies on Russian folklore.)

Slavianskaia mifologiia. V. Ia. Petrukhin, et al., ed. M.: Ellis Lak, 1995.

Slavianskie drevnosti. Vol. 1, A-G. Ed. N. I. Tolstoi. M.: Mezhdunarodnye otnosheniia, 1995. (The first volume of an encyclopedia being prepared by the Institut slavianovedeniia i balkanistiki.) 
Vostochno-slavianskil folklor: Slovar' nauchnoi 1 narodnoi terminologii. K. P. Kabashnikov, et al., eds. Minsk: Navuka i tekhnika, 1993.

Vlasova, M. Novaia abevega russkikh sueverii. SPb.: Severo-zapad, 1995. (A well-prepared illustrated dictionary of folk beliefs.)

VARIOUS WORKS ON FOLKLORE. Many are concerned with rituals, reconstruction of archaic beliefs, or with everyday conduct (povedenie).

Astafeva, L. A. Siuzhet i stil russkikh bylin. M.:

Nauka, 1993.

Baiburin, A. K. Ritual v traditsionnoi kulture. SPb.: Nauka, 1993.

Ekspeditsionnye otkrytiia poslednikh let. Comp. and ed. M. A. Lobanov. SPb: Rossiiskii institut istorii iskusstv, 1996.

Folklor i etnograficheskaia deistvitelnost. Ed. A. K. Baiburin. St. Petersburg: Nauka, 1992. (A collection of articles about mythological texts and rituals, reconstrution of archaic concepts, and analysis of folklore texts.)

Froianov, I. Ia., and Iu. I. Iudin. Bylinnaja istorija. SPb.: Sankt-Peterburgskij universitet, 199?. (A collection of articles by the historian Froianov and Iu. Iudin. They in particular are seeking to trace elements of pre-Kievan society in Russian epics.) Ivanova, T. G. Russkaia folkloristika v biograficheskikh ocherkakh. Studiorum Slavicorum Monumenta, vol. 1. SPb.: RAN, 1993. (A study of nine Russian folklorists around the turn of the twentieth century.)

Ivleva, Larisa. Riazhene v russkoi traditsionnoi kulture. SPb.: Rossiiskii institut istoril iskusstv, 1994. (A fascinating study of mummery and what many would term the grotesque.) 
Jazyk russkogo fol'klora. Ed. Z. K. Tarlanov. Petrozavodsk: Petrozavodskij gosudarstvennyj universitet, 1996. (The most recent volume of an irregular series edited by Tarlanov.) Koshelev, V. V. Skomorokhi: Annotirovannyi bibliograficheskii ukazatel 1790-1994 gg. SPb.: Liki Rossii, 1994.

Kuznetsova, V. P. Prichitaniia v severno-russkom svadebnom obriade. Petrozavodsk: RAN, 1993. Lapin, V. Russkii muzykalnyi folklor i istoriia. M.: Moskovskii gosudarstvennyi folklornyi tsentr "Russkaia pesnia," 1995. (Three essays that challenge widely held ideas about "pan-Russian folklore" and stimulate a new approach toward the study of local traditions.)

Malye formy folklora: Sbornik statei pamiati G. L. Permiakova. M.: Vostochnaia literatura, 1995. Meletinskij, E. M. Poetika mifa. 2nd ed. Moscow: Vostochnaia literatura, 1995. (A reissue of one of the main Russian studies about myth.)

Nasledie Aleksandra Veselovskogo: Issledovaniia i materialy. P. R. Zaborov, et al., eds. SPb.: Nauka, 1992. (A collection of articles reflecting the continuing revival of $A$. Veselovskii)

Novikov, Iu. A. Bylina i kniga. Vilnius: RAN, 1995. (Traces how some epic singers learned their songs from printed sources.)

Pesennaia lirika ustnoi traditsii. Comp. and ed. I. I. Zemtsovskii. SPb.: Rossiiskii institut istorii iskusstv. (A recent volume in the excellent series "Folklor $i$ folkloristika" put out by this institut now under its older name.)

Putilov, B. N. Folklor i narodnaia kultura. SPb.: RAN, 1994.

-.-.-.. Epicheskoe skazitel'stvo. M.: Vostochnaia literatura, 1997. (The last book by the "dean" of Russian epic studies. A study of the epic singer that 
expands the approach of Albert Lord to the Russian tradition as well as to those of various peoples in the former Soviet Union.)

Rudneva, A. V. Russkoe narodnoe tvorchestvo. M.: Kompozitor, 1994. (Collection of articles by an ethnomusicologist.)

Russkaia narodnaia pesnia: Neizvestnye stranitsy muzykalnoi istorii. Ed. amd comp. I. I. Zemtsovskii. SPb.: Rossiiskii institut istorii iskusstv, 1995. ("Folklor i folkloristika")

Russkie. Ed. V. A. Aleksandrov et al. M.: Nauka, 1997. (A huge collection of articles about many aspects of Russian ethnicity, material culture, life, customs, beliefs, and rituals.)

Russkii folklor: Epicheskie traditsii. Vol. 28. SPb.: Nauka, 1995.

Russkii folklor: Materialy i issledovaniia. Vol. 29. SPb.: Nauka, 1996. (The latest volumes of the main scholarly series on Russian folklore.)

Selivanov, F. M. Russkie narodnye dukhovnye stikhi." M.: Mariinskii gosudarstvennyi universitet, 1995. (An anthology with an introduction and detailed bibliography of a long-neglected genre.)

Skomorokhi: Problemy i perspektivy izucheniia. Ed. V. V. Koshelev. SPb.: Rossiiskii institut istorii iskusstv. (Collection of papers given at a conference November 22-26, 1994 and organized by Koshelev, who has revitalized study of the skomorokhs.)

Sokolov, B. M. Bolshoi stikh o Egorii khrabrom. M.: Nasledie, 1995. (Written long ago by one of the finest Russian folklorists in the twentieth century, Boris Sokolov, 1889-1930, it was published only recently. Folklorist V. A. Bakhtin edited the text and includes an introduction and commentary.)

Toporkov, A. L. Teorija mifa v russkoi filologicheskoi nauke XIX veka. Moscow: Indrik, 1997. (A longneeded study of the contributions of all the main 
members of the "mythological school" in Russian folklore in the middle of the 19th century: Buslaev. Afanasev, Potebnia, and A. N. Veselovskil. The author points out how much was derived from the Brothers Grimm and several German philosophers, but also shows how many original ideas the Russian scholars contributed themselves and how their work has led to present day studies of the associations among myth, word, and poetry.)

Trubetskoi, E. N. Izbrannoe. M.: Kanon, 1995. (Includes his fine study about the magic tale. "Inoe tsarstvo.")

Zakharova, O. V. Byliny: Poetika siuzheta. Petrozavodsk: Petrozavodskii universitet, 1997. (Comparative analysis of the "themes" or "scenes" in some of the epics of the Riabinin family.)

\section{COLLECTIONS OF RUSSIAN FOLKLORE. FeW}

volumes of Russian folklore itself seem to have been published in recent years. One important collection of all Russian epics collected in Siberia has been compiled by Smirnov and Shentalinskaia and appears in the new series "Pamiatniki folklora narodov Sibiri i Dalnego Vostoka," which includes excellent collections of the tales and epics of various peoples living in Siberia. A small plastic recording is enclosed with each volume.

Azbelev, S. N., comp. Narodnaia proza. M.: Sovetskaia Rossiia, 1992. (A fine anthology of prose genres including legends of all types and memorates but excluding tales in the series "Biblioteka russkogo folklora.")

Cherepanova, O. A. Mifologicheskie rasskazy i legendy russkogo Severa. SPb.: Sankt-Peterburgskij gos. universitet, 1996. 
Gatsak, V. K., et al., eds. Obriady i obriadovyi folklor. M.: Nasledie, 1997. (A collection of works recorded during the last two centuries in the Moscow area.) Kruglov, Iu. G., comp. Obriadovaia poezlia. Kn. 1 . M.: Russkaia kniga, 1997. (An anthology of calendar folklore in the series "Biblioteka russkogo folklora.") Kulagina, A. V. Russkoe ustnoe narodnoe tvorchestvo. M.: Universitet rossiiskoi akademil obrazovaniia, 1996. (An anthology of Russian folklore for students that includes genres such as dukhovnye stikhi and bylichki.)

Maslennikova, R. A. Otletala lebedushka: Russkii svadebnyi obriad. Orel: Prostor, 1992. (A collection of wedding songs and detailed description of the wedding ceremony in a region where the subject has previously been little investigated.)

Nekrylova, A. F., and N. I. Savushkina, comp.

Narodnyj teatr. M.: Sovetskaia Rossiia, 1991.

(Probably the best and most complete anthology of folk plays, Petrushka, vertep, and urban folklore including the "raëk," in the series "Biblioteka russkogo folklora.")

Onchukov, N. E. Zavetnye skazki. Ed. E. Eremina and V. Zhekulina. M.: Ladomir, 1996.

Smirnov, Iu. I., and T. S. Shentalinskaia, ed. and comp. Russkaia epicheskaia poeziia Sibiri I Dal'nego Vostoka. Novosibirsk: Nauka, 1991.

Tatarintseva, M. P. Russkie narodnye pesni v Tuve.

Kyzyl: Tuvinskil nauchno-issledovatelskii institut iazyka, literatury $i$ istorii, 1993. Narious genres collected over the last decade, includes some melodies.)

Toporkov, A. Russkii eroticheskii folklor. M.: Ladomir, 1995.

Zimin, V. I. and A. S. Spirin, comp. Poslovicy i pogovorki russkogo naroda. M.: Siuita, 1996. 


\section{INSTITUT SLAVIANOVEDENIIA I BALKANISTIKI.}

The group of folklorists at this institute of RAN continues to publish interesting collections of studies on a wide range of subjects and cultural topics. Only a few items are cited from the main series coming out.

Obraz mira v slove i rituale. Balkanskie chteniia I. M.: RAN, 1992.

Simvolicheskil iazyk traditsionnoi kultury. Balkanskie chteniia II. M.: RAN, 1993.

Lingvo-etnokulturnaia istoriia Balkan i Vostochnoi Evropy. Balkanskie chteniia III. M.: RAN, 1994. Issledovaniia v oblasti balto-slavianskoi kultury: Zagovor. M.: Nauka, 1993.

Issledovaniia v oblasti balto-slavianskoi kultury: Zagadka kak tekst I. M.: Nauka, 1994.

\section{STUDIES OF THE LANGUAGE OF RUSSIAN}

FOLKLORE. A. T. Khrolenko and his group in Kursk have in particular focused attention on what he terms "lingvofolkloristika." He is now bringing out two series on the subject.

Byt velikorusskikh krest'ian-zemlepashtsev: Opisanie materialov etnograficheskogo biuro kniazia V.N. Tenisheva. Comps. B. M. Firsov and I. G. Kiseleva. SPb.: Evropeiskii dom, 1993. (Selections from the immensely rich Tenishev archives. Unfortunately all examples of folklore texts have been excluded.) Fol'klor 1994: Problemy tezaurusa. Ed. V. M. Gatsak. M.: Nasledie, 1994. (Yet another volume in the valuable series whose title varies by "Folklore" and the year.)

Fol'klornaia leksikografiia. Vols. 1-4. Ed. A. T. Khrolenko. Kursk: Kurskii gos. ped. institut, 1994-95. 
Issledovaniia po lingvofolkloristike. Vols. 1-2. Ed. A. T. Khrolenko. Kursk: Kurskil gos. ped. Institut, 1994.

Khrolenko, A. T. Semantika fol'klornogo slova. Voronezh: Voronezhskii universitet, 1992. Nevskaia, L. G. Balto-slavianskoe prichitanie: Rekonstruktsiia semanticheskoi struktury. M.: Nauka, 1993.

Nikitina, S. E. Ustnaia narodnaia kultura 1 lazykovoe soznanie. M.: Nauka, 1993. (A linguist and specialist on Old Believers writes about the differences between the written and spoken word in folklore.) Razumova, I. A. Stilisticheskaia obriadnost russkoi volshebnoi skazki. Petrozavodsk: Kareliia, 1991. Tolstoi, N. I. lazyk i narodnaia kultura: Ocherki po slavianskoi mifologii i etnolingvistike. M.: Indrik, 1995. (A collection of articles by another "dean" of Russian and Slavic folklore.)

\section{A FEW REPUBLICATIONS OF OLDER STUDIES OR COLLECTIONS.}

Afanasev, A. N. Narodnye russkie skazki ne dlia pechati, zavetnye poslovitsy i pogovorki. O. B. Alekseeva et al., eds. M.: Ladomir, 1997. (A collection of previously unpublished "erotika.") -.-----.. Poeticheskie vozzreniia slavian na prirodu. 3 vols. M.: Indrik, 1994.

-.-... Proisxozhdenie mifa. M.: Indrik, 1996. -..-.... Zavetnye skazki. SPb.: Boianych, 1994. (Liberally illustrated in lurid lubok style.)

Dal, V. I. O poveriakh, sueveriiakh i predrassudkakh russkogo naroda: Materialy po russkoi demonologii. SPb.: Litera, 1994.

Eleonskaia E. N. Skazka, zagovor 1 koldovstvo v Rossii: Sbornik trudov. Ed. L. N. Vinogradova. M.: Indrik, 1994. 
Famintsyn, A. S. Bozhestva drevnikh slavian. SPb.: Aletei, 1995.

Famintsyn, A. S. Skomorokhi na Rusi. SPb.: Aletei, 1995.

Kostomarov, N. I. Domashniaia zhizn' i nravy velikorusskogo naroda. M.: Ekonomika, 1993. Maikov, L. N. Velikorusskie zaklinaniia. SPb.: Evropeiskii dom, 1994.

Makarenko, A. A. Sibirskil narodnyi kalendar'. Novosibirsk: BO Nauka, 1993.

Maksimov, S. V. Nechistaia, nevedomaia i krestnaia sila. SPb.: Poliset, 1994.

Onchukov, N. E. Zavetnye skazki iz sobranija N. E.

Onchukova. M.: Ladomir, 1996.

Poznanskii, N. Zagovory: Opyt issledovaniia proiskhozhdeniia i razvitiia zagovornykh formul. M.:

Indrik, 1995.

Propp, V. Ia. Russkie agrarnye prazdniki. SPb.: Azbuka, 1995.

Russkoe koldovstvo, vedovstvo, znakharstvo. Ed. M. Sterligov. SPb.: Litera, 1994. Sadovnikov, D. N. Skazki i predaniia Samarskogo kraia. 2 vols. Samara: Samarskii oblastnoi tsentr narodnogo tvorchestva, 1993.

Sadovnikov, D. N. Zagadki russkogo naroda. M.: Sovremennyi pisatel, 1995.

Skaftymov, A. Poetika i genezis bylin. Saratov: Saratovskij universitet, 1994. (A reprint of one of the classic studies of the Russian epic.)

Sumtsov, N. F. Simbolika slavianskikh obriadov. M.: Vostochnaia literatura RAN, 1995.

Varentsov, V. G. Sbornik pesen Samarskogo kraia. Samara: Oblastnoi tsentr narodnogo tvorchestva, 1994.

Zelenin, D. K. Izbrannye trudy. Ocherki russkoi mifologii: Umershie neestestvennoiu smert'iu i rusalki. M.: Indrik, 1995. 
Izbrannye trudy: Stat'i po dukhovnol kul'-

ture 1901-1913. M.: Indrik, 1994.

-..--. Velikorusskie skazki Permskoi gubernil.

Ed. T. G. Ivanova. SPb: RAN, 1997. (Has extremely thorough commentary to the tales.)

-.-.-... Vostochnoslavianskaia etnografila. M.:

Nauka, 1991.

\section{AN EXAMPLE OF AN ANTHOLOGY OF URBAN FOLKIORE.}

Sindalovskii, N. Peterburgskil fol'klor. SPb:

Maksima, 1994. Contains an introduction by B. N.

Putilov and a selection of various genres originating from the eighteenth century to the present day.)

\section{THREE OTHER VOLUMES OF GENERAL INTEREST} DESERVE TO BE MENTIONED.

Foley, John Miles. The Singer of Tales in

Performance. Bloomington: Indiana UP, 1995.

Hilton, Alison. Russian Folk Art. Bloomington:

Indiana UP, 1995. (Gorgeously illustrated.)

Lord, A. B. Skazitel'. Trans. Yu. A. Kleiner and G. A.

Levinton. M.: Vostochnaia literatura, 1994. (With an afterword by B. N. Putilov and articles by Yu. A.

Kleiner and A. I. Zaitsev.) 